\title{
Correction to: Improving decisions with market information: an experiment on corporate prediction markets
}

\author{
Ahrash Dianat $^{1} \cdot$ Christoph Siemroth $^{1}$ \\ Published online: 24 March 2021 \\ (c) Economic Science Association 2021
}

\section{Correction to: Experimental Economics (2021) 24:143-176 https://doi.org/10.1007/s10683-020-09654-y}

Co-author Zultan name missing in citation of article Information aggregation in Arrow-Debreu markets: an experiment

Original article has been updated.

Publisher's Note Springer Nature remains neutral with regard to jurisdictional claims in published maps and institutional affiliations.

The original article can be found online at https://doi.org/10.1007/s10683-020-09654-y.

Christoph Siemroth

christoph.siemroth@essex.ac.uk

Ahrash Dianat

a.dianat@essex.ac.uk

1 Department of Economics, University of Essex, Wivenhoe Park, Colchester CO4 3SQ, UK

包 Springer 